\title{
Strategic Thinking in Family Businesses
}

\author{
Prof. Nicholas O'Regan \\ Professor of Strategy, Bristol Business School, Bristol, BS16 1QY, UK \\ T: 01173283735 \\ nicholas.o'regan@uwe.ac.uk \\ Dr. Tim Hughes \\ Reader in Marketing, Bristol Business School, Bristol, BS16 1QY, UK \\ T: 01173283400 \\ tim.hughes@uwe.ac.uk
}

Dr. Lorna Collins

Principal Lecturer in Strategy, Bristol Business School, Bristol, BS16 1QY, UK

T: 01173283182

lorna.collins@uwe.ac.uk

John Tucker

CEO, International Centre for Families in Business, UK

T: 01173145678

johntucker@icfib.com 


\section{Summary}

- The literature suggests that a lack of strategic thinking is a major obstacle in achieving competitive advantage and that in family businesses strategic thinking is complicated by the intergenerational composition of senior management.

- This research aims to explore the extent to which family businesses engage in strategic thinking and whether or not there are differences between second and third generation managed firms.

- This research also considered the issues which were considered important for strategic consideration, including capital structure and financing for growth.

- A pragmatic-critical realist approach was taken using semi-structured interviews with practitioners, academics and family business experts in order to get a balance of views from different perspectives

- The interviewees were drawn from a population of 20 second and thirdgeneration family businesses.

- The results indicate that strategic thinking is not consistent across family firms; second generation firms focus on operational and tactical level strategy while third generation firms focus on strategic level plans.

- Evidence is presented which highlight the differences between thinking in second and third generation firms and between second generation supply chainled firms and non-supply chain led firms.

- Implications for future research indicate that longitudinal research may reveal how thinking skills in individuals in family businesses may be optimised to provide greater competitive advantage. 
Abstract: This practitioner orientated paper seeks to understand better how management knowledge is created, shared and disseminated in family businesses (FBs). It outlines the initial findings from an exploratory study with senior managers of 20 FBs and FB experts that sought to examine the extent to which FB directors engage in strategic thinking, the issues that are considered part of strategic thinking, and the processes and tools driving strategic decision making. The results indicate that strategic thinking is not consistent across generations of FBs, as second generation (SG) firms tend to focus on operational issues whereas third generation (TG) firms have a more strategic focus. While all generations have to balance the 'business' and 'family' issues, it is likely that the 'family' element will have greater complexities in third generation businesses due to business maturity and extended family involvement. Results also illuminate that certain strategic issues and challenges relating to financing and capital structure, amongst others, are thought of differently in family businesses. Our findings indicate that FBs have differing management strategies, control systems and means of operating that impact on the extent and shape of strategic thinking. Finally, we contend that the present volatile business environment is the ideal time to focus on the development of sound strategic thinking to inform strategic planning which focuses the firm on the changing external environment and encourages a realistic appraisal of possible responses, dealing with threats before they become insurmountable. 


\section{Strategic Thinking in Family Businesses}

\section{Introduction}

Strategic decision-making has long been a topic of great interest in the field of strategic management and is a critical driver in achieving successful strategic change. Strategic decisions are defined as 'important in terms of the actions taken, the resources committed, or the precedents set' (Mintzberg et al., 1976:246). Fundamentally, the effectiveness of the strategic decision-making process determines whether firms are able to change and adapt to their environment and ultimately whether they are successful or fail (Barnett and Burgelman, 1996; Schendel, 1996). Therefore it is no surprise that strategic decision-making is one of the ten most critical and important issues for future management research (Zahra and O’Neill, 1998).

While there is extensive empirical research underpinning the managing of change (Van de Ven and Poole 1995) there is a dearth of research on how strategic decision makers actually make decisions as part of the change process. There is relatively little research that addresses decision making and thinking within the context of family businesses (FBs). This is surprising given the importance of FBs to economies across the world (Neubauer and Lank, 1998; Bornheim, 2000) and in view of the way the 'family' aspect impacts on decision making. Hence the purpose of this exploratory study, with $20 \mathrm{FBs}$, is to seek to if and how family businesses think strategically. 
Though this area of literature is underdeveloped there are studies that suggest that the Resource-Based View (RBV) of competitive advantage can provide a useful framework for assessing this phenomenon within a FB (Habbershon and Williams, 1999). The RBV suggests that there can be heterogeneity or firm-level differences among firms that allow some of them to sustain competitive advantage (Barney, 1991). This approach has a solid underpinning in relation to smaller businesses and FBs (Hunt and Derozier, 2004). In this study we consider that strategic thinking is a skill and asset possessed by the firm that resides in decision-making individuals, in this case senior family member managers (Teece et al., 1997). The study therefore seeks in the first instance to determine if strategic thinking exists or not within FBs and if so what form it takes. We also seek to explore whether or not this thinking differs between second generation and third generation firms.

The paper is structured as follows: first, FB is described from an organisational context. Second, strategic thinking is described with a focus on how it differs from strategic planning. Third the literature on the drivers of strategic thinking is reviewed. Fourth, we briefly examine the impact of strategic planning on overall performance followed by the methodology adopted for the study is described. The analysis of the empirical research is then presented. Finally, conclusions and directions for future research are outlined.

\section{Family business from an organisational context}

FBs are important to the economy of all countries. In the UK FBs comprise up to $75 \%$ of the economy (Neubauer and Lank, 1998; Bornheim, 2000). FBs are considered to be unique in the ways that they evaluate, acquire, integrate and leverage their resources 
(Sirmon and Hitt, 2003), largely resulting from the involvement of the family. Clearly, the involvement of the family in strategic thinking is a critical factor and can be both positive and negative. For example, in the quest for competitive advantage, family involvement can be invaluable in evaluating the external environment and deriving options for advancement (Corbett, 2005; Lumpkin and Lichtenstein, 2005). On the other hand it can also lead to tensions that can lead to negative impact (Kellermanns and Eddleston, 2004). The negative aspects of family involvement often manifest themselves as a generational issue where younger members may advance strategic thinking whereas older and in particular founder members may see a continuation of existing strategies as the way forward (Davis and Harveston, 1999; Harvey and Evans, 1994; Handler. 1992). Tensions also tend to arise when FBs are in a growth mode, when family members need to work with business managers. Davis and Harveston (1999:314) contend that "with shared management comes the threat of organizational paralysis or worse - the continued presence of the senior generation can act as an irritant to the family members or employees." Therefore, generational status is a potentially important factor in strategic thinking and requires the need to distinguish between different types of FBs. There have been calls for more research that compares different types of family business (e.g. Nordqvist, 2005).

The literature shows that FBs are distinctively different from non-FBs with different strategic approaches, management styles, decision making processes and differing investment timeframes (Tagiuri and Davis, 1996; Poza et al., 1997; Baskin, 2001). Research has tended to reflect the view of the family as a positive factor in firm performance (Anderson and Reeb, 2003; McConaughy et al., 2001; Miller et al. 2008; 
Nordqvist, 2005). The view of the family as a unique non-replicable resource in business (Habbershon et al., 2003) puts a new emphasis on understanding the nature of this resource in the FB.

There is no consensus on the definition of FB. Some authors believe that FBs should self type themselves (Westhead, 1997; Gallo et al., 2000). Others seek to define FB in terms of governance (Chua et al., 1999:25):

"...a business governed and/or managed with the intention to shape and pursue the vision of the business held by a dominant coalition controlled by members of the same family or a small number of families in a manner that is potentially sustainable across generations of the family or families".

Although there is no consensus on a definition for the FB, in order to clarify our unit of study we adopted the approach suggested by Handler (1989), namely that we consider four dimensions to define a FB: degrees of ownership and management by family members; independent sub-systems; generational transfer; multiple conditions (a combination of the three former dimensions). These dimensions fit nicely into Fletcher's (2008) typology of family businesses which we used to categorise the sample firms. This typology considers two dimensions of family businesses; ownership of the business and who it is controlled by; and who undertakes management roles in the business. 


\section{Overview of academic relevance in the business and management field of strategic thinking versus strategic planning}

Strategic thinking is seen by Mintzberg et al. (1976: 274) as one of the most important actions for an organisation as it "determines in large part, however implicitly, the subsequent course of action". It is portrayed as a cognitive process addressing the future of the organisation by evaluating alternative approaches to competing in the market place (Critelli, 2005). It is about seeing ahead (Mintzberg et al., 1998) but also about combining prior knowledge and future thinking (Weick, 1983:225). Klayman and Schoemaker (1993) propose that strategic thinking is a way of thinking about the future that involves a knowledge base, a problem representation, and linkages between these two. This implies that strategic thinking consists of analysis leading to innovative options for future competitive advantage (O'Shannassy, 2003; Zabriskie and Huellmantel, 1991). Kaufman (1991:69) describes strategic thinking as "a switch from seeing the organization as a splintered conglomerate of disassociated parts (and employees) competing for resources, to seeing and dealing with the corporation as a holistic system that integrates each part in relationship to the whole". Eisenhardt and Brown (1998:787) encapsulate strategic decision-making as "“constantly shifting and evolving in ways that surprise and confound the competition".

While the literature defines strategic decisions as "important, in terms of the actions taken, the resources committed, or the precedents set" (Mintzberg et al., 1976: 246) there is no agreed or definitive concept of strategic thinking (Bonn 2001; Heracleous, 
1998; O'Shannassy 2003) and a relative scarcity of robust empirical studies into strategic thinking in practice (Dickson et al. 2001; Liedtka 1998).

Mintzberg (1994:110) cautions that 'many practitioners and theorists have wrongly assumed that strategic planning; strategic thinking and strategy making are all synonymous, at least in best practice'. He stresses that 'strategic thinking is not strategic planning' (107) and that each focuses on a different stage of the strategic process, with strategic thinking comprising the analytical and creative stage followed by strategic planning to formalise the developed strategy. Mintzberg et al. (1998:42) argue:

'there are times when thought should precede action, and guide it . . . Other times, however, improving strategic thinking especially during or immediately after major unexpected shifts in the environment, thought must be so bound up with action that 'learning' becomes a better notion than 'designing' for what has to happen. And then, perhaps most common are a whole range of possibilities in between, where thought and action respond to each other'.

Much of the literature makes a clear distinction between strategic thinking and strategic planning (Aggarwal, 1999; Schoemaker, 1995). Graetz (2002:458) states that strategic thinking and planning are "distinct, but interrelated and complementary thought processes" that must sustain and support one another for effective strategic management. Graetz's (2002) model holds that the role of strategic thinking is "to seek innovation and imagine new and very different futures that may lead the company to 
redefine its core strategies and even its industry" (458). Strategic planning's role is concerned with implementation: "to realize and to support strategies developed through the strategic thinking process and to integrate these back into the business". However, other authors have cautioned against making such a distinction due to the interrelated nature of thinking and planning. Floyd and Wooldridge (2000:78) refer to the process of strategic thinking and strategic planning as 'strategic behaviour' that shapes the resultant strategy. They contend that: 'strategies evolve over time, not from discrete decisions but from indeterminate managerial behaviours embedded in a complex social setting'.

For the purposes of this study the important point is that strategic thinking is a distinct activity. We adopted Goldman's (2007:75) definition of strategic thinking for the purposes of this study because it adequately encapsulates the myriad of definitions:

'Distinctive management activity whose purpose is to discover novel, imaginative strategies which can rewrite the rules of the competitive game; and to envision potential futures significantly different from the present'.

\section{Drivers of Strategic Thinking}

One of the key drivers of strategic thinking is the active involvement of senior managers. This implies the development of senior managers as visionaries (EasterbySmith and Davies, 1983). Goldman (2006) contends that a range of factors influences managers' strategic thinking during their formative and working years such as education, colleagues and experience. De Rond and Thietart (2007:536) argue "one 
cannot speak of strategy, or account for performance, without explicitly referencing causal conditions" because "causal conditions are pivotal to freedom of choice and ‘meaningful' randomness'. Zabriskie and Huellmantel (1991:26) state that:

'the need for strategic thinking begins with the premise that both profit and non-profit organisations need leadership. They must be led; they cannot be permitted to drift into the future. Strategic thinking is the prelude to designing an organisation's future. Strategic leaders cannot lead intelligently unless they have a mental blueprint of where they want to go, and how they will get there'.

It is important to note that it is the individual that thinks strategically and not the organisation (Liedtka, 1998), but the individual is influenced by the organisational context in which he or she operates. Bonn (2001) sees strategic thinking at the individual level encompassing three main elements. The first element is holistic understanding of the organisation and its environment with an emphasis on how different problems and issues interact. Second, a degree of creativity is needed where innovative solutions to issues are introduced that challenge existing approaches and thinking. Woodman et al. (1993:293), for example, defined creativity as "the creation of a valuable, useful new product, service, idea, procedure, or process by individuals working together in a complex social system". Creativity "often involves recombining or making connections between things that may seem unconnected" (Robinson and Stern, 1997:14). De Bono (1996:17) has made this point very clear: 
"Without creativity we are unable to make full use of the information and experience that is already available to us and is locked up in old structures, old patterns, old concepts, and old perceptions".

Third, a vision of the future that inspires and unites people in the achievement of the corporate goals is critical. Weick (1995:27) stresses the importance of "values, priorities, and clarity about preferences".

Goldman (2007:79) contends that strategic thinking is the result of continually asking the 'same three questions: where are we going?; how are we getting there?; and are we executing efficiently? She contends that there are three instrumental patterns in the development of strategic thinking;

1. Repetitive process of using past experiences to consider alternative perspectives. This might enable problems to be looked at from new or different angles

2. A logical planning process - understanding where you are, determining where you want to be and detailing how to get there. Each stage is informed by information and experience as well as discussion.

3. A developmental pattern of tackling bigger and bigger business challenges as the ability to thinking strategically continually grows.

We used Goldman's instrumental patterns framework to evidence how SG and TG firms' think differently. Strategic thinking is seen as a key to organisational success (Finkelstein and Hambrick, 1996), and an activity that managers and others within the 
organisation undertake (Jarzabkowski et al., 2007; Whittington, 2006). There is strong underpinning for strategic thinking and its positive impact on organisational performance in the literature (Bonn, 2001; Mason, 1986). Indeed, the literature contends that strategic planning is now more important than ever due to the degree of environmental turbulence (Hartman and Crow, 2002). Liedtka (1998a:32) contends that in the increasingly volatile operating environment, strategic thinking is 'central to creating and sustaining competitive advantage'. Porter (1996) argues that many companies fail to distinguish between operational effectiveness and strategy as they are increasingly driven by conditions emanating from a volatile operating environment. Furthermore, Bonn (2001) contends that the blurring of the lines between operational effectiveness and strategy is a consequence of a lack of strategic thinking that ultimately leads to organisational failure. Bonn (2001) argues that the development and integration of strategic thinking at organizational and individual levels is both a core competence and a driver of competitive advantage. Others echo this as they stress that a lack of strategic thinking is a major obstacle in achieving competitive advantage (Essery, 2002).

The ethos of strategy and consequently strategic thinking has changed over the past decade, as research moves from an organisational focus to become more people and strategist orientated (Whittington, 2003; Samra-Fredericks, 2003; Jarzabkowski, 2005). This trend is mirrored by the extant research (Balogun and Johnson, 2005; Rouleau, 2005). Sull (2007:30) suggests that 'in fast-paced industries, companies should think of strategy as an iterative loop with four steps: making sense of a situation, making 
choices, making things happen and making revisions.' In a recent interview Sull (2008) ${ }^{1}$ argued that:

'the most successful firms, at least in turbulent markets, follow a more iterative approach, where leaders first make sense of the situation, then make choices about what to do, what not to do and what to stop doing, then make it happen by executing on agreed objectives, and finally making revisions by revisiting initial assumptions and comparing them against what actually happened. An iterative process views strategy and execution as intimately linked, and indeed inseparable.

Sull's iterative loop offers a relatively new way of viewing strategic thinking in firms and to our knowledge has not been applied in the family business context before. The iterative loop view embraces the notion of successful firms operating in turbulent markets it was deemed appropriate to use it to illustrate the differences between strategy making in second and third generation firms.

\section{Research questions}

Arising from the dearth of literature on strategic thinking, the literature strongly suggests that more time and effort be allocated to understanding how strategic managers think. For example Stubbart (1989:326) contends that "since strategic management studies the activities of managers, and since managers must think about strategy, why don't researchers allocate more research to studying how strategic managers think?" Similarly, Garratt (1995:2) called for more research "in the underrated study of strategic

\footnotetext{
${ }^{1}$ http://www.ibscdc.org/executive-interviews/Q\&A_with_Don_Sull_2.htm date accessed online 19 August 2009.
} 
thinking”. From a practitioner perspective, strategic thinking is a major challenge for many top managers (Bonn, 2001; Zabriskie and Huellmnatel, 1991; Zahra and O'Neill, 1998). The literature shows that top managers influence strategy but there is little evidence on how they communicate their interpretation of the strategy formulated or how it is embedded within ongoing, persistent organisational actions (Maitlis, 2005).

This exploratory research addresses the following questions:

RQ1 - What strategic thinking takes place within family businesses, and what form does it take?

Family businesses are important but strategic thinking in them is an under-researched area (Ibrahim et al., 2004). Very little research has been undertaken on how strategy is shaped in family businesses (Litz, 1997; Chua et al., 2003). The aims of this study were to explore strategic thinking in family firms and observe how thinking is shared and disseminated to bring about change. In investigating this question a number of key areas of strategic concern were used to stimulate thought and to facilitate the exploration of thinking and dissemination. The stimulus issues included;

- availability of finance

- capital structure of the firm

- tax planning and tax structure

- profitability and margins

- cash flow and controlling costs

While the main thrust of this paper is not to focus specifically on any one of these issues and how it is considered within the family business (this is for another paper), we do highlight selected insights from the most illuminating results that relate to the availability of finance and capital structure of the firm later in the paper. 


\section{RQ2 - How does strategic thinking differ between second generation and third generation firms?}

The strategic decision making process and thinking in family firms is different from non-family firms (Ibrahim et al., 2004) however little is known about how strategic decisions are made in family firms (Ibrahim et al., 2004) and if there is a difference in family firms which are in different generational stages of development.

\section{Data and methods}

A critical realist (CR) approach was adopted for this study which fundamentally focuses on the extent to which society can "be studied in the same way as nature" (Bhaskar, 1998:1). Bhaskar (1998) suggests that reality is made up of three different layers; the empirical layer which can be observed by humans; the actual layer which exists in time and space; and the real layer which goes beyond facts, perceptions and experiences. He adds that the real layer is the one that encompasses structures which have powers and liabilities which allow observable events to emerge. Furthermore Bhaskar argues that social phenomena surface from real structures which then become 'actual' and finally are empirically observable.

The CR approach adds value in management study as the approach allows contextualised comparisons to be made and causal explanations to be investigated (Edwards, 2006). CR is relatively new to organization and management studies, and significant critical commentary is only just beginning to emerge (Willmott, 2005; Contu and Willmott, 2005). 
$\mathrm{CR}$ attempts to go beyond the "surface phenomena and disclose 'deep' social structures," (Brown et al., 2002). Bhaskar (1989) suggests that the social world is the direct result of human action, thus there remains the possibility that by changing the way individuals act or react will consequently alter existing relationships and if social reality is made up of "causal structures it must be possible to intervene and manipulate structures" (Johnson and Duberley 2000:161). Though beyond the scope of this study, future research may lead to the ability to identify how causal structures might be manipulated in order to aid the strategic thinking of FBs.

Taking a 'pragmatic-critical realism' approach means looking at "social constructions which are bounded by the tolerance of external reality and which exist independently of our cognitive processes" (Johnson and Duberley, 2000:157). There are few studies of strategy in FBs which have adopted a pragmatic-critical realist approach. Given this approach and the complex social environment in which strategic thinking takes place it was deemed appropriate to use semi-structured 'in-depth' interviews to probe the respondents' answers in some depth (Healy, and Perry, 2000). This takes into account individual and shared ideas in peoples' minds as well as the social context prevailing (Magee, 1985). In addition, 'depth' interviews are considered to be appropriate for theory-building within this paradigm (Healy and Perry, 2000). The research questions are situated within the context of the resource-based view (RBV) of business strategy, where strategic thinking is a core competence which resides in individuals. This approach has a solid underpinning in relation to smaller business and FB (Hunt and Derozier, 2004). 
Our methods stress the validity of the research through getting close access to the phenomenon under study (Gummeson, 2002). For this exploratory study we adopted a 4 step process:

1. A focus group meeting with a FB advisory team was conducted to obtain an overview FB strategy and decision making.

2. Two FB forums were attended to outline the research [interim and final research findings were presented].

3. Twenty in-depth interviews with owners/founders of FBs. An aid memoir was used and interviews were taped. Based on the transcript we prepared a report and sent it to the respondents for comments and made changes to our conclusions as necessary. This offers the opportunity to triangulate understandings.

4. Four 'depth' interviews with academic experts in FB.

We contacted 50 companies from a purchased list of SG and TG firms which were considered to be family owned. From this initial contact 20 firms were chosen at random and interviewed. Five FB experts were included in the sample population and their selection was made on the basis of their credibility and expertise in the area of research; a practice that is well established in management research (Marshall and Rossman, 1989). Interviews were semi-structured allowing interviewees to go into as much depth as necessary in areas of particular interest. Interviews were recorded and transcribed and coded using Nvivo software. In collectively analysing the qualitative data the authors' collective experience of the politics of both practice and academia was 
found to be invaluable in assessing the significance of what was said by the interviewees.

\section{Analysis}

The composition of the population is outlined in Table 1 below:

[table 1 goes here] 
Table 1 - Composition of sample population

\begin{tabular}{|c|c|c|}
\hline Number of firms in total & 20 & \\
\hline & Second Generation Firms & Third Generation Firms \\
\hline Number of firms & 17 & 3 \\
\hline Sectors represented & $\begin{array}{l}\text { Professional }=5 \\
\text { Construction }=2 \\
\text { Manufacturing }=3 \\
\text { Retail }=7\end{array}$ & $\begin{array}{l}\text { Professional }=2 \\
\text { Construction }=1\end{array}$ \\
\hline Percentage of sample & $85 \%$ & $15 \%$ \\
\hline Average size & $<250$ employees & $<500$ employees \\
\hline $\begin{array}{l}\text { Family Business type as per } \\
\text { Fletchers' typology } \\
\text { Table } 2 \text { (see } \\
\text { explanations) }\end{array}$ & $\begin{array}{l}1 b=1 \\
1 c=4 \\
2 c=5 \\
2 d=6 \\
3 b=1\end{array}$ & $2 \mathrm{~d}=3$ \\
\hline
\end{tabular}


The twenty respondent firms were classified into family business types using Fletcher's (2008) typology of FBs. The typology considers two dimensions; ownership of the business and who it is controlled by; and who undertakes management roles in the business. Table 2 below shows the categories represented in our sample population in bold. Appendix 1 describes the individuals who were interviewed, their role within the firm, and whether their firm was second or third generation.

[Table 2 goes here] 
Table 2 - Family Business Typology (adapted from Fletcher, 2008; Litz, 1995)

\begin{tabular}{|c|c|c|c|c|c|}
\hline & & \multicolumn{4}{|c|}{ Management roles undertaken in the business by: } \\
\hline \multirow{4}{*}{ 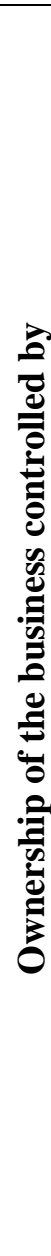 } & $\begin{array}{l}\text { 1.Widely } \\
\text { held } \\
\text { (family and } \\
\text { non-FBs) }\end{array}$ & $\begin{array}{l}\text { 1a.A business } \\
\text { with wide } \\
\text { ownership } \\
\text { (family and non- } \\
\text { family) but with } \\
\text { one person } \\
\text { managing }\end{array}$ & $\begin{array}{l}\text { 1b.A business } \\
\text { with wide } \\
\text { ownership but a } \\
\text { couple manage } \\
\text { the business }\end{array}$ & $\begin{array}{l}\text { 1c.A business } \\
\text { with wide } \\
\text { ownership but a } \\
\text { family team } \\
\text { manage the } \\
\text { business }\end{array}$ & $\begin{array}{l}\text { 1d.A business with } \\
\text { widely held } \\
\text { ownership and } \\
\text { management (PLC). } \\
\text { Not a FB }\end{array}$ \\
\hline & $\begin{array}{l}\text { 2.Family } \\
\text { (siblings or } \\
\text { family } \\
\text { members } \\
\text { from two } \\
\text { generations }\end{array}$ & $\begin{array}{l}\text { 2a.Business } \\
\text { owned by a } \\
\text { family but only } \\
\text { one family } \\
\text { member has a } \\
\text { management role } \\
\text { in the business }\end{array}$ & $\begin{array}{l}2 \mathrm{~b} . \text { Ownership is } \\
\text { held between } \\
\text { wider family } \\
\text { but a couple } \\
\text { from the family } \\
\text { run/manage the } \\
\text { business }\end{array}$ & $\begin{array}{l}\text { 2c.Ownership is } \\
\text { held between } \\
\text { family members } \\
\text { who are also } \\
\text { widely involved } \\
\text { in management } \\
\text { roles - Classic } \\
\text { FB }\end{array}$ & $\begin{array}{l}\text { 2d.Family owned } \\
\text { company with widely } \\
\text { held management } \\
\text { involving family and } \\
\text { non family } \\
\text { (professionalised } \\
\text { business) }\end{array}$ \\
\hline & $\begin{array}{l}\text { 3.Couple } \\
\text { (spouse or } \\
\text { household) }\end{array}$ & $\begin{array}{l}\text { 3a.Couple jointly } \\
\text { own a business } \\
\text { but only one of } \\
\text { them is directly } \\
\text { involved in } \\
\text { management }\end{array}$ & $\begin{array}{l}\text { 3b.Couple own } \\
\text { the business and } \\
\text { are jointly } \\
\text { involved in } \\
\text { managing the } \\
\text { business (classic } \\
\text { copreneurship) }\end{array}$ & $\begin{array}{l}\text { 3c.Couple own } \\
\text { the business but } \\
\text { other family } \\
\text { members are } \\
\text { involved in } \\
\text { managing the } \\
\text { business }\end{array}$ & $\begin{array}{l}3 \text { d.Business owned by } \\
\text { a couple but with } \\
\text { widely held } \\
\text { management }\end{array}$ \\
\hline & 4.Individual & $\begin{array}{l}\text { 4a.Classic start } \\
\text { up whereby an } \\
\text { individual owns } \\
\text { and manages the } \\
\text { business by } \\
\text { themselves }\end{array}$ & $\begin{array}{l}\text { 4b.One } \\
\text { individual owns } \\
\text { the business but } \\
\text { a couple } \\
\text { manage it }\end{array}$ & $\begin{array}{l}\text { 4c. One individual } \\
\text { owns the business } \\
\text { but wider family } \\
\text { members } \\
\text { involved }\end{array}$ & $\begin{array}{l}\text { 4d.Non FB with } \\
\text { individual ownership } \\
\text { and widely held } \\
\text { management }\end{array}$ \\
\hline
\end{tabular}


In order to determine what kind of strategic thinking was going on in these firms we posed a series of questions to each senior manager. The questions formed an outline framework and were grouped into three main categories for the purposes of exploring aspects of strategic thinking as indicated by Goldman (2007)(list of questions is provided in Appendix 2). The results of these questions have been summarised into Goldman's (2007) framework of instrumental patterns of strategic thinking in Table 3 below. The remainder of this section is devoted to a discussion of these findings.

[Table 3 goes here] 
Table 3 - Goldman (2007) Instrumental Patterns of Strategic Thinking Development - Typical Firm Comparisons

\begin{tabular}{|c|c|c|c|}
\hline Pattern & Evidence in SG Firms - Supply chain focused & $\begin{array}{l}\text { Evidence in SG Firms - Non-supply chain } \\
\text { focused }\end{array}$ & Evidence in TG Firms \\
\hline $\begin{array}{l}\text { Repetitive } \\
\text { process of } \\
\text { using past } \\
\text { experiences to } \\
\text { consider } \\
\text { alternative } \\
\text { perspectives }\end{array}$ & $\begin{array}{l}\text { Reliance on customer's knowledge and past } \\
\text { experience to consider alternatives } \\
\text { More trust and faith in customer experience than } \\
\text { family member experience } \\
\text { Strategic tools - customer centric information } \\
\text { valued highly }\end{array}$ & $\begin{array}{l}\text { Relying on experience of Board members and } \\
\text { senior family members } \\
\text { Reliance on past experience of senior family } \\
\text { members - experiences of family members are } \\
\text { considered more valuable than experts } \\
\text { Comparison of results from strategic tools - using } \\
\text { results from previous use of tools to inform and } \\
\text { compare to current situation }\end{array}$ & $\begin{array}{l}\text { Frequent discussions with partners re: revisions } \\
\text { and adjustments to the business plan } \\
\text { Extra/higher level of reliance on external experts } \\
\text { - accountants } \\
\text { Comparison of results from strategic tools - using } \\
\text { results from previous use of tools to inform and } \\
\text { compare to current situation }\end{array}$ \\
\hline $\begin{array}{l}\text { Logical } \\
\text { planning } \\
\text { process - } \\
\text { understanding } \\
\text { where you are, } \\
\text { determining } \\
\text { where you want } \\
\text { to be and } \\
\text { detailing how to } \\
\text { get there }\end{array}$ & $\begin{array}{l}\text { Business purpose is to 'please its customers' } \\
\text { Customer needs formed basis of conceptual } \\
\text { framework for strategic planning } \\
\text { Planning process mostly driven by customers: } \\
\text { Adaptation and adoption of human resources and } \\
\text { supply chain planning cycles used by larger } \\
\text { customers drives planning process }\end{array}$ & $\begin{array}{l}\text { Clear articulation of company purpose } \\
\text { Project planning often used as conceptual } \\
\text { framework for strategic planning } \\
\text { Communicating and networking with others to } \\
\text { informally benchmark against competitors } \\
\text { Where you are and where you want to be is } \\
\text { determined by family members, typically with } \\
\text { founding family member being arbiter of final } \\
\text { direction and giving definitive authorisation }\end{array}$ & $\begin{array}{l}\text { Shared sense of understanding - implicit trust in } \\
\text { 'right thinking' of decision makers } \\
\text { Conceptual framework for strategic planning often } \\
\text { idiosyncratic } \\
\text { Planning process sometimes driven by } \\
\text { customers: Adaptation and adoption of human } \\
\text { resources and supply chain planning cycles used } \\
\text { by larger customers drives planning process }\end{array}$ \\
\hline $\begin{array}{l}\text { Developmental } \\
\text { pattern of } \\
\text { tackling bigger } \\
\text { and bigger } \\
\text { business } \\
\text { challenges as } \\
\text { the ability to } \\
\text { thinking } \\
\text { strategically } \\
\text { continually } \\
\text { grows. }\end{array}$ & $\begin{array}{l}\text { 'Can do' attitude - not saying 'No' to customers } \\
\text { Adaptation and adoption of processes used by } \\
\text { larger customers drives thinking development } \\
\text { Ability to develop strategic thinking brought about } \\
\text { by influx of new people }\end{array}$ & $\begin{array}{l}\text { Determination to tackle bigger business } \\
\text { challenges related to founder values and vision } \\
\text { Level of personal risk taking of founder and senior } \\
\text { family members highly influential on willingness of } \\
\text { business to tackle issues. }\end{array}$ & $\begin{array}{l}\text { Adaptation and adoption of processes used by } \\
\text { larger customers drives thinking development } \\
\text { Strategic thinking is ingrained in company culture } \\
\text { - impact of new people not so disruptive to } \\
\text { strategic thinking development }\end{array}$ \\
\hline
\end{tabular}

Source: Goldman (2007) framework showing primary data interpreted by authors. 
FBs are viewed as adopting a long term perspective that is underpinned by a rational approach to strategic thinking and decision making (Arnoff and Ward, 1994). This means that many decisions are taken with the forthcoming generation in mind. Others argue that this is not the case and that FBs are risk averse (Gallo et al., 2000; Daily and Dollinger, 1992). Accordingly, we asked respondents if they had one overarching set of clear and challenging outcomes, aims and objectives that provide long term direction.

'The overarching aim for the company is the provision of employment for those within it - in essence the family members. The company evolved from the need to create employment - it just grew from there. Of course performance is the ultimate aim of the company but employment is the main goal.' (SGP4)

The degree of emphasis given to vision by a third generation firm is in marked contrast:

'We have an annual business plan that is committed to by the partners. This is adopted at the AGM and rarely needs review before the next AGM. This determines the direction of the firm. The plan is formulated after due discussion by the partners - all of whom have significant experience in the business'. (TG2)

However, it is clear that while there is a movement away from employment creation to direction, the direction is motivated by the annual business plan rather than visionary ideas. Arguably, this is a means of bridging the employment creation objective with performance. Another firm indicated that they have 'little time for strategic thinking as we have to deal with fighting day to day problems'. (SG6) 
Only one firm indicated that they use strategic thinking to determine the vision for the company;

'We think of our vision in terms of what we call 'strategic space' and are keenly aware that any business that expects to grow will need to think strategically. We see the 'strategic space' as a means towards sharing knowledge and information about where we want the business to be' (SG8).

The views of this firm are unrepresentative of the companies interviewed and relate to a family member having recently completed an MBA at one of the leading business schools. We asked interviewees to describe the processes that their firms used to determine key success factors in order to ascertain if they pursue strategic thinking indirectly;

'You know where you are going and others trust your judgement. If I met my senior staff members and told them that 'this is my vision for the future', they would not understand or care' (SGP2).

The FB experts we interviewed concurred that terms like direction setting, managing strategy and managing change are rarely used in SG firms and are used to a limited extent in TG firms. Referring to a recent project that his team have completed, a FB expert stressed;

SG firms rarely use the word 'strategy'. They don't talk about scanning the environment - they talk about communicating with customers, networking and so on. 
They refer to a project as from start to finish - this may mean strategy formulation and deployment but they do not use such terms. (FBE 4)

Other experts agreed that instead of talking about vision and strategic planning, terms such as decision making, communicating externally and internally, and managing performance are used by FBs. This is consistent with the analysis of the interviews conducted with FB respondents.

\section{Strategic thinking and key success factors}

While the majority of FBs do not use the term 'strategic thinking' they do tend to plan for the future in terms of key performance objectives as evidenced by intentional actions that are often not formalised. While we did not find any FB referring to the scanning of the operating environment, we did find that most referred to communicating with customers, networking and so on. This is probably due to disconnection between the languages that academics use and those used by FBs. Table 5 below provides an illustrative example of the iterative loop of strategic thinking employed in typical SG and TG firms.

[Table 5 goes here] 
Table 5 - Sull's Iterative Loop of Strategic Thinking - Illustrative Examples

\begin{tabular}{|l|l|l|}
\hline $\begin{array}{l}\text { Steps in } \\
\text { Iterative Loop }\end{array}$ & $\begin{array}{l}\text { Typical Second Generation Firm } \\
\text { (SGP4) }\end{array}$ & Typical Third Generation Firm (TGP2) \\
\hline $\begin{array}{l}\text { Making sense } \\
\text { of a situation }\end{array}$ & $\begin{array}{l}\text { Individual focus: Reading financial } \\
\text { papers and trade papers which } \\
\text { highlighted possible recession }\end{array}$ & $\begin{array}{l}\text { Collaborative focus: Informal } \\
\text { conversations with contemporaries in } \\
\text { comparable industries } \\
\text { Informal chats with colleagues in } \\
\text { informal surroundings }\end{array}$ \\
\hline Making choices & $\begin{array}{l}\text { Reliance on factual data: Reviewing } \\
\text { weekly reports from accountants }\end{array}$ & $\begin{array}{l}\text { Non-important decisions - Informed } \\
\text { through information gathered } \\
\text { informally } \\
\text { Very important decisions - Formal risk } \\
\text { assessments carried out }\end{array}$ \\
\hline $\begin{array}{l}\text { Making things } \\
\text { happen }\end{array}$ & $\begin{array}{l}\text { Reducing workforce long before } \\
\text { recession } \\
\text { Adjusting output targets }\end{array}$ & $\begin{array}{l}\text { Non-important decisions - things } \\
\text { happen through normal management } \\
\text { mechanisms } \\
\text { Very important decisions - Plan is } \\
\text { implemented following risk assessment }\end{array}$ \\
\hline $\begin{array}{l}\text { Making } \\
\text { revisions }\end{array}$ & $\begin{array}{l}\text { Revising targets for output in light } \\
\text { of changing financial information }\end{array}$ & $\begin{array}{l}\text { Non-important decisions - informal } \\
\text { discussions with colleagues and } \\
\text { industry contacts } \\
\text { Very important decisions - Risk } \\
\text { assessment process followed }\end{array}$ \\
\hline
\end{tabular}

Source: Sull (2007) framework with primary data interpreted by authors. 
Many firms referred to a project as from start to finish - this could be construed as referring to strategy formulation and deployment. While we expected to hear terms such as direction setting, managing strategy, managing change and so forth, we were continually told about decision making, communicating externally and internally and managing performance. The reason for this is;

'we tend to have a more strategic approach since bringing people in from outside the firm with large firm experience'. (SGP 6)

Many of these processes were pursued instinctively;

'The major issue that contributes to the success of the company is service - I do not have 'No' in my vocabulary. If someone wants a task completed, I will do so as quickly, cheaply and effectively for them while also making a profit.' (SGP 1)

'Issues that arise are how to grow the business by maximising the sale per customer. We have a list of existing customers and contact them periodically to ascertain if their needs have changed and if so, how we can help them'. (SGP9)

In both cases, the most dominant process was that of managing performance. Other FBs interviewed were part of a supply chain, where their customers were driving the non financial performance objectives and ultimately were key determinants of overall profitability: 
'Aspects such as quality requirements, $H R$ requirements and links with large companies force us to adopt what larger firms might see as routine initiatives'. (SGP10)

From our interviews, it was clear that businesses not in a supply chain situation did not have this type of influence on their activities. In Table 6 below we present an illustrative example that highlights these differences.

[Table 6 goes here] 
Table 6 - Sull's Iterative Loop of Strategic Thinking - Supply Chain versus nonsupply chain family businesses

\begin{tabular}{|l|l|l|}
\hline $\begin{array}{l}\text { Steps in } \\
\text { Iterative Loop }\end{array}$ & $\begin{array}{l}\text { Supply chain } \\
\text { Second Generation (SGP10) }\end{array}$ & $\begin{array}{l}\text { Non-supply Chain } \\
\text { Second Generation (SG6) }\end{array}$ \\
\hline $\begin{array}{l}\text { Making sense } \\
\text { of a situation }\end{array}$ & Reliance on customer's knowledge & $\begin{array}{l}\text { Reliance on senior family members } \\
\text { knowledge }\end{array}$ \\
\hline Making choices & $\begin{array}{l}\text { Customer needs form basis of } \\
\text { conceptual framework for making } \\
\text { choices }\end{array}$ & $\begin{array}{l}\text { Management data informed } \\
\text { Instinctual and consensual choice senior } \\
\text { managers }\end{array}$ \\
\hline $\begin{array}{l}\text { Making things } \\
\text { happen }\end{array}$ & $\begin{array}{l}\text { 'Can do' attitude - not saying 'No' } \\
\text { to customers - organization } \\
\text { culture is driver }\end{array}$ & $\begin{array}{l}\text { Reliance on management systems and } \\
\text { processes rather than culture }\end{array}$ \\
\hline $\begin{array}{l}\text { Making } \\
\text { revisions }\end{array}$ & $\begin{array}{l}\text { Revision driven by customer } \\
\text { needs and demands }\end{array}$ & $\begin{array}{l}\text { Ability to develop strategic thinking } \\
\text { brought about by influx of new people }\end{array}$ \\
\hline
\end{tabular}

Source: Sull (2007) framework with primary data interpreted by authors.

We found that FBs pursue a range of management styles that facilitate the development of strategic thinking. In higher performing companies there are overlaps between processes where performance is part of communication and culture and is therefore embedded in the way the company does business. In other firms there is often a crisis which precipitates the need to think strategically. 


\section{Finance issues}

A detailed discussion about how family business deal with financial planning is beyond the scope of this paper. In trying to determine why it is that family businesses seem to be more successful than non-family business in recessionary times, we posed a number of questions about financial planning and growth.

The lifeblood of a company's financial health and growth is capital and reinvested capital, while the capital structure is the skeleton. Capital structure is the particular combination of debt, equity, and finance that is used for long term financing. More importantly, capital gearing, that is the relative weights of each capital source that makes the capital structure, can denote the orientation priority of funds that firms have.

How family firms use capital at their disposal, and the planning method associated with it, i.e. investment appraisal or capital budgeting, is important to long-term growth and success. The Modigliani Miller theorem of capital structure or capital gearing states that in a perfectly competitive market where there is no tax, no bankruptcy cost, equal information, and complete market efficiency, the value of the firm is unaffected by how a firm is financed (Simerly and Mingfang, 2007). Therefore, in a perfectly competitive market, capital structure is independent of company value. This is called the capital structure irrelevance principle. Capital gearing is the measurement of the proportion between debt and equity in a capital structure. However, there are a number of reasons that make the Modigliani Miller theorem unrealistic in the real world. Most importantly is the trade off theory of capital structure, which states that a tax advantage on debt and the bankruptcy cost of debt is a duality of trade off for the company. The higher the debt a company incurs the marginal benefit of further increases decline while the marginal 
cost rises. Therefore, a company must have the right trade-off between tax benefits and debt cost to arrive at the optimum debt-equity ratio.

According to Romano et al. (2001) there is a complex array of factors that influence SME owner-managers' financing decisions. Recent family business literature suggests that these processes are influenced by firm owners' attitudes toward the utility of debt as a form of funding as moderated by external environmental conditions (e.g., financial and market considerations). Furthermore pecking order theory, which suggests that there is a hierarchy for financing decisions and this hierarchy is governed by the firm's priorities according to least effort, refutes the Modigliani Miller theorem. The hierarchy starts with financing capital through internal funds, followed by financing through debt, then the use of equity (Liesz, 2007).

In the case of the family business in this study, each was asked about their thinking and approach with respect to financial planning and the capital structure of their businesses. From there responses it was possible to gain an illuminating view of the position of family businesses. Family businesses in the service industry seem to be less likely to use family loans as are those owners who are planning to achieve growth through new products or process development. When asked about their thinking on using capital and retained profits to achieve growth, the response was that they are likely to take this approach if they were seeking to achieve growth through an increase in sales. Those from the manufacturing sector and lifestyle firms said that they would be less likely to take this approach.

None of the firms had formal financial planning processes in place. None had used or sought equity funding and the majority intimated that they would not consider equity 
financing in any circumstances. Our findings seem to support the work of other family business scholars (Romano et al., 2001; De Bodt et al., 2005; Lopez-Gracia and SanchezAndujar, 2007) because they indicate that equity does not seem to be a consideration for owners of large businesses, young firms, and owners who plan to achieve growth through increasing profit margins. Equity also seems to be an unlikely option for older family business owners and owners who have a preference for retaining family control. It also supports the notion that a business's family nature does lead it to employ financial policies that are different from non-family businesses.

\section{Discussion and implications}

Our analysis builds on the basic premise that strategic thinking can drive firm performance (Zahra and O’Neill, 1998). Terms such as strategy and strategic thinking are rarely used in second generation family business although the actions carried out adhere to some of the traits and characteristics of strategic thinking. In third generation family businesses, these terms are used more frequently and many of the actions taken adhere to the traits of strategic thinking. Our findings echo the assertions of Johnson and Duberley (2000) as in this study we did not 'lack the necessary cognitive and linguistic means of apprehending' the reality we observed, but what we observed was that a different linguistic understanding was being applied. We were able to understand the context, and appreciate it was constructed in a linguistically different way than we expected.

The nature of the strategic thinking that we found was often expressed in relation to the needs of the family in relation to managing the performance of the firm or meeting the needs of customers. This is of significant interest for anyone involved in the family firm arena. Policy makers and advisors to family firms need to consider the implications of the language used when promoting strategic thinking to family businesses. Researchers need 
to look beyond traditional formal planning and performance objectives to understand the range of practice of strategic thinking in FBs. In particular, understanding how the current strategy has developed and how it has been influenced by not only the family elements, but also other key contextual elements such as position in the supply chain and the influence of key customers. Future research might also consider how strategic thinking skills which reside within individuals in FBs might be utilized for competitive advantage. This assumes that such skills allow individuals (and firms) to develop specific asymmetries (Miller, 2003) which may give them a unique competitive advantage and that ultimately may contribute to the success and performance of their FB. Understanding better how these skills are utilised effectively in the FB context will help policy makers and advisors in providing meaningful support to those FBs with the most potential for development.

Our findings indicate that strategic thinking is given greater attention in third generation family businesses - which arguably secures their competitive advantage foundations. Indeed, it could be argued that the lack of formalised strategic thinking is one of the reasons for the high attrition rate of FB firms from second to third generation. Understanding what happens in the transition from SG to TG and whether this triggers specific changes that require a more formal approach to strategy would be valuable. How far are changes are attributable to particular aspects of FBs and how far are they simply related to the age/maturity of the business are questions for further research. Comparative studies between FBs and non FBs at different stages of maturity would be informative in this respect. 


\section{Conclusions}

Our study was essentially exploratory and in the light of the small size of this sample, care must be exercised in the interpretation of the research findings, especially as one attempts to generalise these to these to broader populations. The findings do suggest, however, that strategic thinking is not consistent across generations of FBs with a focus on every day operational aspects in SG firms to a more strategic focus in TG firms. We would further observe that there are different linguistic and cognitive constructions of strategic thinking in operation in SG and TG firms.

It could and undoubtedly will be argued by many FBs that in the current environment their emphasis has to be on survival and that strategic thinking is therefore not their first priority. The authors would argue that, on the contrary, it is precisely when the business environment is undergoing rapid change, as in the current circumstances, that effective strategic thinking is most beneficial. Discontinuity and turbulence in an increasingly global business environment will potentially destroy the efficacy of existing business models and points of competitive advantage faster than ever before. Strategic thinking orientates the organisation to the changing external environment and encourages a realistic appraisal of possible responses, dealing with threats before they become insurmountable. Our research sheds some light on how far this happens within different types of FB and indicates some directions for further research in this important area. 
Appendix 1: Details of interviewees

\begin{tabular}{|l|l|}
\hline Name & Role \\
Practitioners & \\
\hline SGP 1 & Director of a family business \\
\hline SGP 2 & Director of a family business \\
\hline SGP 3 & Director of a family business \\
\hline SGP 4 & Director of a family business \\
\hline SGP 5 & Director of a family business \\
\hline SGP 6 & Director of a family business \\
\hline SGP 7 & Director of a family business \\
\hline SGP 8 & Senior Manager \\
\hline SGP 9 & Senior Manager \\
\hline SGP 10 & Senior Manager \\
\hline Third Generation Practitioners & \\
\hline TGP 1 & Director \\
\hline TGP 2 & Director \\
\hline TGP 3 & Director \\
\hline Family Business Experts & \\
\hline FBE 1 & Consultant \\
\hline FBE 2 & Academic \\
\hline FBE 3 & Senior official of national body representing FBs \\
\hline FBE 4 & Consultant \\
\hline FBE 5 & Consultant \\
\hline
\end{tabular}


Appendix 2 - In-depth Interview Questions Framework

\section{Vision (Individual thinking of senior manager - past experiences):}

- Do you have one overarching set of clear and challenging outcomes, aims and objectives that will improve the overall performance of the firm?

- What issues are of major importance to the growth and success of the firm?

- How do you decide what targets you have?

- How is vision formulated and communicated?

- How do you maintain growth and work levels?

- How do you deal with new competitors entering the market?

2.Participation (Integration and dissemination of thinking - planning process and developmental aspects)

- How do staff members participate in decision making?

- How would you characterise your firm?

- How do you integrate all parts of the organisation in decisions made?

\section{Making changes (ability grow and adapt strategic thinking)}

- What is your approach to risk taking?

- How do you overcome problems?

- How do you identify future trends and plan for them?

- How do you choose between a range of options

- What are the main sources of knowledge used in strategic thinking?

- What are the barriers to getting this knowledge? 


\section{Bibliographical Notes}

Nicholas O'Regan is Professor of Strategy/Enterprise and Innovation at Bristol Business School. His research interests include the organisational culture, leadership and strategic planning processes of small and medium sized organisations. He has published widely in journals such as Technovation, the International Small Business Journal, and the Journal of General Management.

Dr. Tim Hughes is Reader in Applied Marketing at Bristol Business School. Previously he worked for 17 years within large companies in senior management positions and ran his own consultancy for 7 years. He has published in journals such as European Journal of Marketing and Journal of Marketing Management. The current focus of his research is on academic/practitioner knowledge exchange across the range of management disciplines.

Dr. Lorna Collins is Principle Lecturer in Strategy (Enterprise \& Creativity) at Bristol Business School. She ran her own company for 15 years. She has published articles in Management Learning, Personnel Review, Journal of Small Business and Enterprise Development, Education + Learning. Her research interests are succession and the role of women in family business and the genesis of new entrepreneurial firms.

John Tucker is Director of the International Centre for Families in Business. He ran his own company for 15 years and is now an international consultant to family businessess. 


\section{References}

Aggarwal, R. (1999) 'Technology and globalization as mutual reinforcers in business: Reorienting strategic thinking for the new millennium', Management International Review, 39: 83-104.

Anderson, R.C. and Reeb, D.M. (2003) 'Founding family ownership and firm performance; evidence from the S\&P 500', Journal of Finance. 58:1301-1328.

Archer, M. S. (2000) Being Human: The Problem of Agency, Cambridge University Press, Cambridge.

Aronoff, C. E. and Ward, J. L. (1994) 'Set policies to solve future problems', Nations Business, 82(7), 1994.

Balogun, J. and Johnson, G. (2005) 'From Intended Strategy to Unintended Outcomes: The impact of change recipient sense making', Organization Studies, 26 (11): 15731602.

Barnett, W. and Burgelman, R. (1996) 'Evolutionary perspectives on strategy', Strategic Management Journal. 17: 5-19.

Barney, J. (1991) 'Firm Resources and Sustained Competitive Advantage', Journal of Management Review 17(1), 99-120.

Baskin, O.W. (2001) 'Trust as a competitive advantage: why FBs have an edge in the global marketplace', The Graziadio Business Report, Spring, 2001.

Bhaskar, R., (1989) Reclaiming Reality: A Critical Introduction to Contemporary Philosophy. Verso, London.

Bonn, I. (2001) "Developing strategic thinking as a core competency." Management Decision 39(1): 63-70.

Bornheim, S. (2000) The organizational form of FB, Massachusetts, Kluwer Academic Publishers.

Brown, A., Slater, G., and Spencer, D. A., (2002) "Driven to Abstraction? Critical Realism and the Search for the 'Inner Connection' of Social Phenomena" Cambridge Journal of Economics, 26 (13)

Chua, J. H., Chrisman, J.J. and Sharma, P. (1999) 'Defining the FB by Behaviour', Entrepreneurship Theory and Practice 23(4), 19-39.

Chua, J. H., Chrisman, J.J. and Sharma, P. (2003) Succession and non-succession concerns of family firms and agency relationship with non-family members, Family Business Review, XVI(2):89

Contu, A. Willmott, H. (2005) 'You Spin Me Round: The Realist Turn in Organization and Management Studies', Journal of Management Studies, 42 (8). 
Corbett, A. C. (2005) 'Experiential Learning within the Process of Opportunity Identification and Exploitation', Entrepreneurship Theory \& Practice 29(4):473-491.

Critelli, M. (2005) 'Back where we belong', Harvard Business Review, May 2005, 83(5):47-54.

Daily C. M. and Dollinger, M. J. (1992) 'An empirical examination of ownership structure in family and personally managed firms', FB Review, 5 (2).

Davis, P. S., and P. D. Harveston (1999) "In the Founder's Shadow: Conflict in the FB," FB Review, 12(4): 311-323.

De Bodt, E., Lobez, F. and Statnik, J.C. (2005) 'Credit Rationing, Customer Relationship and the Number of Banks: An Empirical Analysis.' European Financial Management. 11(2): 195-228.

De Bono, E. (1996) Serious Creativity, HarperCollins Business, London.

De Rond, M. and Thietart, R.A. (2007) "Choice, chance, and inevitability in strategy." Strategic Management Journal 28(5): 535-551.

Dickson, P. R., Farris, P. W. and Verbeke, W. J. M. I. (2001) "Dynamic strategic thinking." Journal of the Academy of Marketing Science, 29(3): 216-237.

Edwards, P. (2006) 'Industrial Relations and Critical Realism: IR's Tacit Contribution.' Warwick Papers in Industrial Relations No. 80 March 2006.

Easterby-Smith, M and Davies, J. (1983) 'Developing Strategic Thinking', Long Range Planning, 16(4):39-48.

Eisenhardt, K.M., Brown, S.L. (1998), 'Competing on the edge: strategy as structured chaos', Long Range Planning, 31(5):786-9.

Essery, E. (2002) 'Reflecting on Leadership', Works Management, 7(55):54.

Finkelstein, S. and Hambrick, D.C. (1996) Strategic leadership: Top Executives and their effects on organizations, West: St Paul, MN.

Fletcher, D.E. (2008) Overview of FB Relevant Issues - UK, Project conducted on behalf of the European Commission, Enterprise and Industry Directorate-General. Accessed:

http://ec.europa.eu/enterprise/entrepreneurship/craft/family_business/family_business_en htm (Date accessed: 3 August 2009)

Floyd, S.W., Wooldridge, B. (2000) Building strategy from the middle: Reconceptualising strategy process. Sage Publications: Thousand Oaks.

Gallo, M.A., Tapies, J. and Cappuyns, K. (2000) 'Comparison of family and non-FB: financial logic and personal preferences', IESE Research Paper No 406 bis, January, 2000. 
Garratt, B. (1995) 'Helicopters and rotting fish: developing strategic thinking and new roles for direction-givers', in Garratt, B (Eds), Developing Strategic Thought Rediscovering the Art of Direction-Giving, McGraw-Hill, London, pp.242-55.

Goldman, E.F. (2007) 'Strategic thinking at the Top', Sloan Management Review, 48(4):75-81.

Goldman, E. (2006) 'Strategic Thinking at the Top: What Matters in Developing Expertise', Academy of Management Conference Proceedings 2006, pF1-F6.

Graetz, F. (2002), "Strategic Thinking versus Strategic Planning: Towards Understanding the Complementarities", Management Decision, 40(5/6), 456-462

Gummeson, E. (2002) 'Practical value of adequate marketing management theory', European Journal of Marketing, 36(3):325-349.

Habbershon, T.G. and Williams, M.L. (1999) 'A Resource-Based Framework for Assessing Strategic Advantages of FBs'. FB Review, 12(1):1-25.

Habbershon, T.G. Williams, M. and McMillan, I. (2003) 'A unified systems perspective on FB performance', Journal of Business Venturing, 18, 467-472.

Handler, W.C. (1992) 'The Succession Experience of the Next Generation', FB Review, 5(3):283-307.

Handler, W.C. (1989) 'Methodological issues and considerations in studying FBes, FB Review, 2(3): 257-276.

Hartman, S.J., and Crow, S.M. (2002) 'Executive development in healthcare during times of turbulence: Top management perceptions and recommendations', Journal of Management in Medicine, 16(5).

Harvey, M., and R. E. Evans (1994) 'FB and Multiple Levels of Conflict', FB Review 7(4):331-348.

Healy, M. and Perry, C. (2000) 'Comprehensive criteria to judge validity and reliability of qualitative research within the realism paradigm', Qualitative Market Research: An International Journal, Vol. 3, No. 3, pp. 118-126.

Heracleous, L. (1998) 'Strategic thinking or strategic planning', Long Range Planning 31(3): 481-487.

Hunt, S. D., and Derozier, C. (2004) 'The Normative Imperatives of Business and Marketing Strategy: Grounding Strategy in Resource-Advantage Theory', Journal of Business and Industrial Marketing 19(1):5-22.

Ibrahim, A.B., McGuire, J.. Soufani, K., Poutziouris, P. (2004) Patterns in strategy formation in a family firm. International Journal of Entrepreneurial Behaviour and Research. 10(1/2): 127-140.

Jarzabkowski, P. (2005) Strategy as Practice: An Activity-Based Approach. UK: Sage. 
Jarzabkowski, P., Balogun, J. and Seidl, D. (2007) 'Strategizing: The Challenge of a Practice Perspective'. Human Relations, 60 (1).

Johnson, P. and Duberley, J. (2000) Understanding Management Research, Sage, London.

Kaufman, R. (1991) Strategic Planning Plus: An Organizational Guide, Scott Foresman, Glenview, IL.

Kellermanns, F. W., and Eddleston, K. (2004) 'Feuding Families: When Conflict Does a FB Good', Entrepreneurship Theory and Practice 28(3): 209-228.

Klayman, J. and Schoemaker, P. J. H. (1993) 'Thinking about the future - a cognitive perspective', Journal of Forecasting 12(2): 161-186.

Liedtka, J. M. (1998a) 'Linking strategic thinking with strategic planning', Strategy \& Leadership 26(4): 30-35.

Liedtka, J. M. (1998) 'Strategic thinking: Can it be taught?' Long Range Planning 31(1): 120-129.

Lincoln, Y. and Guba, E. (1985) Naturalistic Inquiry, Sage, California.

Liesz, TJ. (2007). Why Pecking Order Should Be Included in Introductory Finance Courses.

Available: http://www.mountainplains.org/articles/2001/pedagogy/PECKING\%20ORDER\%20THE ORY.htm Date accessed 18 November 2009

Litz, R.A. (1995) 'The Family Business: Toward Definitional Clarity', Family Business Review, Volume 8(2): 71-81.

Litz, R.A. (1997) The family firm's exclusion from business chool research: explaining the void, addressing opportunity, Entrepreneurship Theory and Practice, 21:55-71.

Lopez-Gracia, J., Sanchez-Andujar, S. (2007) 'Financial Structure of the Family Business: Evidence from a group of small Spanish firms.' Family Business Review, 20(4):269-287.

Lumpkin, G. T. and Lichtenstein, B.B. (2005) 'The Role of Organizational Learning in the Opportunity Recognition Process', Entrepreneurship Theory \& Practice 29(4), 451472.

Magee, B. (1985), Popper, Fontana, London.

Maitlis, S. (2005) 'The social processes of organisational sensemaking', Academy of Management Journal, 48(1):21-49.

Marshall, C. and Rossman, G. (1989) Designing Qualitative Research. Sage: London Mason, J. (1986) 'Developing strategic thinking', Long Range Planning 19(3): 72-80. 
McConaughy, D.L. Matthews, C.H. and Fialco, A.S. (2001) 'Founding family controlled firms: performance, risk and value', Journal of Small Business Management, 39, 31-49.

Miller, D. (2003) 'An asymmetry-based view of advantage: towards an attainable sustainability’, Strategic Management Journal, 24(10): 961-976.

Miller, D. Le Breton-Miller, I. and Scholnick, B. (2008) 'Stewardship vs Stagnation: An Empirical Comparison of Small Family and Non-FBes', Journal of Management, 45(1), 51-78.

Mintzberg, H., Raisinghani, D., and Theoret, A. (1976) " The Structure of "Unstructured" Decisions', Administrative Science Quarterly, 21: 246-275.

Mintzberg, H. (1994) 'The fall and rise of strategic planning', Harvard Business Review, pp.107-14.

Mintzberg, H., Ahlstrand, B. and Lampel, J. (1998) Strategy Safari. New York NY: The Free Press.

Neubauer, F. and Lank, A.G. (1998) The FB: its governance for sustainability, London, Macmillan Press, 1998.

Neustadt, R.E. and May.R.E. (1986) Thinking in Time: The Uses of History for Decisionmakers. New York, Free Press.

Nordqvist, M (2005) 'Families in Top Management Teams: Commentary on Ensley and Pearson's “An Exploratory Comparison of the Behavioral Dynamics of Top Management Teams in Family and Nonfamily New Ventures: Cohesion, Conflict, Potency, and Consensus" Entrepreneurship Theory and Practice, May, pp. 1042-2587.

O'Shannassy, T. (2003) 'Modern strategic management: Balancing strategic thinking and strategic planning for internal and external stakeholders', Singapore Management Review 25(1): 53-68.

Porter, M. E. (1996) ‘What is strategy?’ Harvard Business Review 74(6): 61-78.

Poza, E. J., Alfred, T. and Maheshwari, A. (1997) 'Stakeholder perceptions of culture and management practices in family and FBs; a preliminary report', FB Review, 10 (2).

Robinson, A.G. and Stern, S. (1997) Corporate Creativity. Business \& Professional Publishing, Warriwood.

Romano, C.A. Tanewski, G.A. Smyrnios, K.X. (2001) 'Capital Structure Decision Making: A model for family business.' Journal of Business Venturing 16(3):285-310.

Rouleau, L. (2005) 'Micro-practices of strategic sensemaking and sensegiving: how middle managers interpret and sell change every day', Journal of Management Studies, 42 (7): 1413-1443.

Samra-Fredericks, D. (2003) 'Strategizing as lived experience and strategists' everyday efforts to shape strategic direction', Journal of Management Studies, 40 (1): 141-174. 
Schendel, D. (1996) 'Evolutionary perspectives on strategy', Strategic Management Journal, Vol. 17, pp. 1-4.

Schoemaker, P. J. H. (1995) 'Scenario planning: A tool for strategic thinking', Sloan Management Review 36(2): 25-40.

Simerly, R.L. and Mingfang, L. (2007) 'Re-thinking the Capital Structure Decision.' Available: http://www.westga.edu/ bquest/2002/rethinking.htm Date accessed 18 November 2009.

Sirmon, D. G., and Hitt, M.A. (2003) 'Managing Resources: Linking Unique Resources, Management, and Wealth Creation in FBs', Entrepreneurship Theory and Practice 27(4), $339-358$.

Stubbart, C.I. (1989) 'Managerial cognition: a missing link in strategic management research', Journal of Management Studies, 26:325-47.

Sull, D.N. (2007) 'Closing the gap between strategy and execution', Sloan Management Review, 48(4):30.

Tagiuri, R. and Davis, J. (1996) 'Bivalent attributes of the FB', FBReview, 9 (2).

Teece, D.J., Pisano, G., and Shuen, A. (1997) Dynamic capabilities and strategic management. Strategic Management Journal, 18:509-533.

Van de Ven, A. and Poole, M. (2005) 'Alternative approaches for studying organizational change', Organization Studies, 26(9):1377-1404.

Weick, K.E. (1983) 'Managerial thought in the context of action', in Srivastva, S. (Ed.), The Executive Mind. New Insights on Managerial Thought and Action, Jossey-Bass, San Francisco, CA, pp. 221-42.

Weick, K.E. (1995) Sensemaking in Organizations. Sage: Thousand Oaks, CA.

Westhead, P. (1997) 'Ambitions, "external" environment and strategic factor differences between family and non-family companies', Entrepreneurship and Regional Development, 9 (2), 1997.

Whittington, R. (2003) 'The work of strategizing and organizing: For a practice perspective', Strategic Organization, 1 (1): 119-127.

Whittington, R. (2006) 'Completing the practice turn in strategy research', Organization Studies. 27(5): 613-634.

Willmott, H. (2005) 'Theorizing Contemporary Control: Some PostStructuralist Responses to Some Critical Realist Questions', Organization, 2(5).

Woodman, R.W., Sawyer, J.E. and Griffin, R.W. (1993) 'Toward a theory of organizational creativity’, Academy of Management Review, 18:293-321.

Zabriskie, N. B. and Huellmnatel, A. B. (1991) 'Developing strategic thinking in senior management', Long Range Planning 24(6): 25-32. 
Zahra, S. A. and O'Neill, H. M. (1998) 'Charting the landscape of global competition: Reflections on emerging organizational challenges and their implications for senior executives', Academy of Management Executive 12(4): 13-21. 